\title{
Ruminococcus champanellensis sp. nov., a cellulose-degrading bacterium from human gut microbiota
}

\author{
Christophe Chassard, ${ }^{1}$ Eve Delmas, ${ }^{1}$ Céline Robert, ${ }^{1}$ Paul A. Lawson ${ }^{2}$ \\ and Annick Bernalier-Donadille ${ }^{1}$ \\ ${ }^{1}$ Unité de Microbiologie, INRA, Centre de Recherches de Clermont Ferrand - Theix, \\ 63122 Saint Genès-Champanelle, France \\ ${ }^{2}$ Department of Botany and Microbiology, University of Oklahoma, Norman, OK 73019, USA
}

Annick Bernalier-Donadille annick.bernalier@clermont.inra.fr
A strictly anaerobic, cellulolytic strain, designated $18 \mathrm{P}_{13}{ }^{\top}$, was isolated from a human faecal sample. Cells were Gram-positive non-motile cocci. Strain $18 \mathrm{P}_{13}{ }^{\top}$ was able to degrade microcrystalline cellulose but the utilization of soluble sugars was restricted to cellobiose. Acetate and succinate were the major end products of cellulose and cellobiose fermentation. 16S rRNA gene sequence analysis revealed that the isolate belonged to the genus Ruminococcus of the family Ruminococcaceae. The closest phylogenetic relative was the ruminal cellulolytic strain Ruminococcus flavefaciens ATCC $19208^{\top}$ (<95\% 16S rRNA gene sequence similarity). The DNA G $+C$ content of strain $18 \mathrm{P} 13^{\top}$ was $53.05 \pm 0.7 \mathrm{~mol} \%$. On the basis of phylogenetic analysis, and morphological and physiological data, strain $18 \mathrm{P} 13^{\top}$ can be differentiated from other members of the genus Ruminococcus with validly published names. The name Ruminococcus champanellensis sp. nov. is proposed, with $18 \mathrm{P}_{13}{ }^{\top}\left(=\mathrm{DSM} 18848^{\top}=\mathrm{JCM} 17042^{\top}\right)$ as the type strain.
The human large intestine harbours a large diversity of bacterial communities that play a key role in health and disease through their involvement in nutrition, pathogenesis and immunology (Cummings \& Macfarlane, 1991; Salminen et al., 1998). A proper understanding of the diversity and functionality of species in the human gut ecosystem is therefore of considerable importance. Over the past 20 years, the microbiota composition has been investigated using both culture- and molecular-based methods and results have revealed the extensive diversity of this ecosystem (Eckburg et al., 2005; Chassard et al., 2008b; Qin et al., 2010). The microbiota is mainly composed of bacteria belonging to three major phyla: 'Bacteroidetes', 'Firmicutes' and 'Actinobacteria'. The genus Ruminococcus represents an important phylogenetic taxon, belonging to phylum 'Firmicutes', and corresponds to 5$15 \%$ of the total bacterial population in the colon (Chassard et al., 2008b; Ramirez-Farias et al., 2009).

Presently, the genus Ruminococcus is not monophyletic and is divided into two phylogenetically separate groups.

Abbreviation: DMA, dimethyl acetal.

The GenBank/EMBL/DDBJ accession number for the 16S rRNA gene sequence of strain $18 \mathrm{P} 13^{\top}$ is AJ515913.

Two supplementary figures and two supplementary tables are available with the online version of this paper.
Group I is located within rRNA cluster IV and includes Ruminococcus flavefaciens, the type species of the genus. In the latest edition of Bergey's Manual of Systematic Bacteriology, members of group I were included in the family Ruminococcaceae and should be considered as Ruminococcus sensu stricto (Rainey, 2009a). Members of group II are located within rRNA cluster XIVa, which is now recognized as the family Lachnospiraceae, a large group of phenotypic and phylogenetic heterogeneous genera (Rainey, 2009b). Recently, a number of misclassified Ruminococcus species and a Clostridium species in group II were reclassified in the genus Blautia (Liu et al., 2008). The remaining ruminococci within group II most likely constitute the nuclei of novel genera and should not be considered true ruminococci.

The genus Ruminococcus comprises anaerobic Grampositive cocci with a fermentative metabolism for which carbohydrates, but not amino acids, serve as substrates for growth (Hungate, 1966; Rainey \& Janssen, 1995). $R$. flavefaciens and Ruminococcus albus, isolated from the rumen, are the only Ruminococcus species able to degrade cellulose (Flint et al., 2008). Ruminococcus bromii and Ruminococcus callidus, isolated from the human gut, are able to degrade other complex polysaccharides such as starch or xylan (Leitch et al., 2007). However, the presence of cellulolytic Ruminococcus-like strains in the human 
gut was reported by Robert \& Bernalier-Donadille (2003). More recently, a real-time PCR analysis was developed to quantify cellulose-degrading ruminococci in human faeces and used to confirm their presence in the human gut, especially in methane-excreting individuals (Chassard et al., 2010). The present study reports the isolation and characterization of a novel cellulose-degrading isolate from human faeces, strain $18 \mathrm{P} 13^{\mathrm{T}}$, which belongs to the genus Ruminococcus.

During an investigation of the cellulose-degrading community of the human gut, we isolated five cellulolytic, Gram-positive, anaerobic cocci from two healthy human faecal samples (Robert \& Bernalier-Donadille, 2003). The isolates were assigned to the genus Ruminococcus on the basis of 16S rRNA gene sequence analysis, their closest relatives being $R$. flavefaciens ATCC $19208^{\mathrm{T}}$ and $R$. callidus ATCC $27760^{\mathrm{T}}$. The isolates were further shown to represent a new phylogenetic lineage and could be quantified by PCR using specific primers (Chassard et al., 2010). Two isolates, strains $18 \mathrm{P} 13^{\mathrm{T}}$ and $25 \mathrm{~F} 8$, shared $>99 \% 16 \mathrm{~S}$ rRNA gene sequence similarity. Strain $18 \mathrm{P} 13^{\mathrm{T}}$ was chosen for further analysis as it was the most efficient in degrading microcrystalline cellulose.

Strain $18 \mathrm{P} 13^{\mathrm{T}}$ was isolated from a fresh faecal sample of a 38 -year-old methane-excreting healthy human female who had not received antibiotics in the last 3 months, had no diagnosed gastrointestinal disease, consumed a diverse Western diet that included at least $15 \mathrm{~g}$ dietary fibre per day and had a normal body mass index $\left(18-25 \mathrm{~kg} \mathrm{~m}^{-2}\right)$. The isolation procedure has been described previously (Robert \& Bernalier-Donadille, 2003). Briefly, faecal dilutions were inoculated into liquid basal cellulolytic (BC) medium containing $100 \mathrm{mg}$ Whatman no. 1 filter paper as the sole energy source. Cellulolytic strains were isolated from the highest dilution showing filter paper degradation, using solid BC medium containing $0.7 \%$ (w/v) hydrated Sigmacell 50 cellulose as the sole energy source. Strain $18 \mathrm{P} 13^{\mathrm{T}}$ was isolated using the roll-tube technique (Hungate, 1969) from the $10^{-8}$ dilution. Strain $18 \mathrm{P} 13^{\mathrm{T}}$ was routinely cultivated in $\mathrm{BC}$ medium and its growth and phenotypic characteristics were determined in semi-synthetic BC medium (Robert \& Bernalier-Donadille, 2003). Strain $18 \mathrm{P}^{2} 3^{\mathrm{T}}$ was stored at $-80{ }^{\circ} \mathrm{C}$ on solid medium.

Cell morphology and motility were determined using 18-h-old cultures grown with cellobiose by phase-contrast microscopy and electron microscopy after negative staining of the whole cell with $2 \%$ uranyl acetate. Gram staining was performed with the conventional stain. Cell morphology and wall structure were further observed by transmission electron microscopy (Philips 400) of ultrathin sections after staining with uranyl acetate and lead citrate (Bernalier et al., 1996).

Cells of strain $18 \mathrm{P}^{\mathrm{T}} 3^{\mathrm{T}}$ were cocci (about $1.3 \mu \mathrm{m}$ in diameter). Cells stained Gram-positive and thin sections showed a Gram-positive cell-wall structure (Supplementary Fig. S1, available in IJSEM Online). Negatively stained cells revealed the absence of flagella. Viable cells were not recovered from cultures held at $100{ }^{\circ} \mathrm{C}$ for $10 \mathrm{~min}$ and no spores were detected either in cellulose- or cellobiose-grown cultures incubated for more than 15 days at $37^{\circ} \mathrm{C}$. Strain $18 \mathrm{P} 13^{\mathrm{T}}$ was unable to grow on agar plates and was thus cultivated on agar medium using the roll-tube technique with $100 \% \mathrm{CO}_{2}$ in the gas phase. Colonies on $\mathrm{BC}$ medium containing cellobiose were white with a brown centre, translucent, circular with entire margins and $1.5-2.5 \mathrm{~mm}$ in diameter after $24 \mathrm{~h}$.

DNA extraction, amplification and sequencing of the $16 \mathrm{~S}$ rRNA gene of strain $18 \mathrm{P} 13^{\mathrm{T}}$ were performed as reported previously (Chassard et al., 2008a). Briefly, cells were grown for $24 \mathrm{~h}$ in $50 \mathrm{ml} \mathrm{BC}$ medium containing $2 \mathrm{~g}$ cellobiose $1^{-1}$, harvested by centrifugation and subjected to DNA extraction (Easy DNA kit; Invitrogen). The 16S rRNA gene was amplified using the universal primers F8 and 1492R. Sequencing reactions were performed with the Dye Terminator Cycle Sequencing Ready Reaction kit (Perkin Elmer), according to the manufacturer's instructions. The closest known relatives were determined by performing database searches using FASTA (Lipman \& Pearson, 1985). These sequences and those of other related strains were retrieved from GenBank and aligned with the newly determined sequences using SEQtools (Rasmussen, 2002). The resulting alignment was corrected manually using GeneDoc (Nicholas et al., 1997). A phylogenetic tree was constructed according to the neighbour-joining method (Saitou \& Nei, 1987) and a bootstrap analysis was performed with 1000 replications using SEQtools and TreeView (Page, 1996).

An almost-complete sequence of the 16S rRNA gene $(1368 \mathrm{nt})$ of strain $18 \mathrm{P} 13^{\mathrm{T}}$ was obtained. Phylogenetic analysis (Fig. 1) revealed that the isolate was most closely related to members of ruminococcal group I, the genus Ruminococcus, and this cluster was supported by a high bootstrap value $(93 \%)$. All of the major nodes were confirmed by maximum-parsimony analysis (data not shown). Within the cluster, strain $18 \mathrm{P} 13^{\mathrm{T}}$ was most closely related to one of the cellulolytic strains from the rumen in the family Ruminococcaceae, $R$. flavefaciens ATCC $19208^{\mathrm{T}}$, with which it shared $<95 \%$ 16S rRNA gene sequence similarity. The other cellulolytic strain from the rumen, $R$. albus ATCC $27210^{\mathrm{T}}$, exhibited only $86 \%$ 16S rRNA gene sequence similarity with strain $18 \mathrm{P} 13^{\mathrm{T}}$. Of the strains from the human gut, the closest relative to strain $18 \mathrm{P}^{1} 3^{\mathrm{T}}$ was R. callidus ATCC $27760^{\mathrm{T}}$ (88\% 16S rRNA gene sequence similarity). Although there is no precise correlation between 16S rRNA gene sequence divergence and species delineation, it is generally recognized that a divergence value $>3 \%$ is significant (Stackebrandt \& Goebel, 1994) and more recent data have demonstrated that this value can be decreased to $1.3 \%$ without loss of resolution (Stackebrandt \& Ebers, 2006). Therefore, the tree topology and the 16S rRNA gene sequence divergence $(5 \%)$ showed that the isolate represents a novel species in the genus Ruminococcus. 


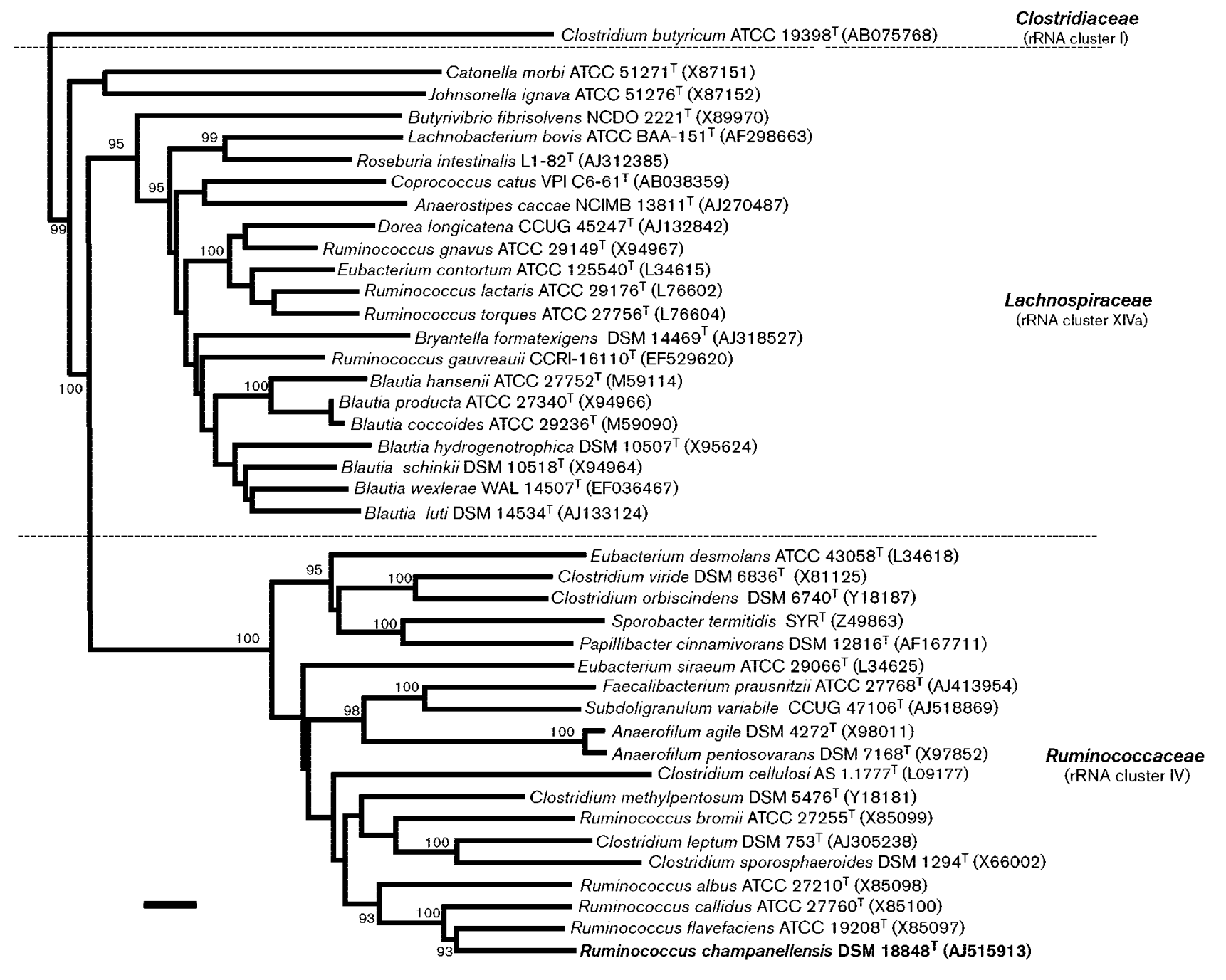

Fig. 1. Unrooted neighbour-joining tree based on 16S rRNA gene sequences (approx. $1320 \mathrm{nt}$ ), showing the phylogenetic relationships between strain $18 \mathrm{P} 13^{\top}$ and some members of the families Ruminococcaceae and Lachnospiraceae. Bootstrap values $(>90 \%)$ based on 1000 replications are shown at branch nodes. Bar, $1 \%$ sequence divergence.

The $\mathrm{G}+\mathrm{C}$ content of the genomic DNA was determined using HPLC by the DSMZ (Braunschweig, Germany). The cellular fatty acids were also determined by the DSMZ, according to the Microbial Identification System (Microbial ID). The DNA $\mathrm{G}+\mathrm{C}$ content of strain $18 \mathrm{P} 13^{\mathrm{T}}$ was $53.05 \pm 0.7 \mathrm{~mol} \% \quad(n=4)$, which was much higher than values reported for the genus Ruminococcus (e.g. 39$44 \mathrm{~mol} \%$ for $R$. flavefaciens ATCC $19208^{\mathrm{T}}, 42.6-45.8 \mathrm{~mol} \%$ for R. albus ATCC $27210^{\mathrm{T}}$ and $43 \mathrm{~mol} \%$ for R. callidus ATCC $27760^{\mathrm{T}}$; Buchanan \& Gibbons, 1974; De Vos et al., 2009) and constituted a distinguishing characteristic. The predominant fatty acids of strain $18 \mathrm{P}_{13} 3^{\mathrm{T}}$ were iso- $\mathrm{C}_{15: 0}(26.57 \%)$, anteiso$\mathrm{C}_{15: 0}(19.56 \%)$, iso- $\mathrm{C}_{15: 0}$ dimethyl acetal (DMA; $11.94 \%$ ) and iso- $\mathrm{C}_{16: 0}(8.84 \%)$ (Supplementary Table S1, available in IJSEM Online). This finding was consistent with the finding of Allison et al. (1962), who found that $R$. albus and $R$. flavefaciens produced 15- and 16-carbon fatty acids.
The presence of catalase and cytochrome oxidase was examined by standard methods. Growth at $25-45{ }^{\circ} \mathrm{C}$ (at intervals of $1{ }^{\circ} \mathrm{C} ; \mathrm{pH} 6.8$ ) and at $\mathrm{pH}$ 5.5-7.5 (at intervals of $0.1 \mathrm{pH}$ units; $37{ }^{\circ} \mathrm{C}$ ) was determined in semi-synthetic $\mathrm{BC}$ medium containing $2 \mathrm{~g}$ cellobiose $\mathrm{l}^{-1}$, with the $\mathrm{pH}$ adjusted using $\mathrm{NaHCO}_{3}$. Other physiological, biochemical and enzyme activity tests were performed using API 20 A, API $50 \mathrm{CH}$ and API ZYM kits (bioMérieux), according to the manufacturer's instructions, with incubation at $37{ }^{\circ} \mathrm{C}$ in an anaerobic chamber.

The results of the phenotypic analysis are given in Table 1 and the species description. Strain $18 \mathrm{P}^{3^{\mathrm{T}}}$ was strictly anaerobic and required an $\mathrm{O}_{2}$-free medium $\left(100 \% \mathrm{CO}_{2}\right.$ headspace) at a redox potential sufficient to decolourize resazurin $\left(\mathrm{E}^{\prime}{ }_{0}=-50 \mathrm{mV}\right)$. Cells of strain $18 \mathrm{P} 13^{\mathrm{T}}$ did not possess catalase or cytochrome oxidase, as observed in $R$. 
Table 1. Characteristics useful in the differentiation of strain $18 \mathrm{P} 13^{\top}$ from its closest phylogenetic neighbours

Strains: 1, Ruminococcus champanellensis sp. nov. $18 \mathrm{P} 13^{\mathrm{T}} ; 2, R$. flavefaciens ATCC $19208^{\mathrm{T}} ; 3$, R. albus ATCC $27210^{\mathrm{T}} ; 4$, R. callidus ATCC $27760^{\mathrm{T}}$. Data for columns 2 and 3 were taken from Buchanan \& Gibbons (1974) and Rainey (2009a) and for column 4 from this study and Rainey (2009a). All strains are negative for catalase and fermentation of arabinose and mannitol. +, Positive; w/-, weakly positive or negative; - , negative; ND, no data available.

\begin{tabular}{|lcccc|}
\hline Characteristic & $\mathbf{1}$ & $\mathbf{2}$ & $\mathbf{3}$ & $\mathbf{4}$ \\
\hline Cell size $(\mu \mathrm{m})$ & $0.9-1.3$ & $0.8-0.9$ & $0.8-2$ & $0.7-0.9$ \\
Gram stain & + & + & + & + \\
Fermentation of: & & & & \\
$\quad$ Cellulose & + & + & + & - \\
Xylan & + & + & + & + \\
Starch & - & - & - & + \\
Glucose & - & - & + & + \\
Cellobiose & + & + & + & + \\
Lactose & - & + & + & + \\
Mannose & - & - & + & - \\
Maltose & - & - & - & + \\
Raffinose & - & - & - & + \\
Sucrose & - & - & + & + \\
$\quad$ Xylose & - & - & - & W/- \\
Major fermentation & A,S & A,F,E & A,E & ND \\
products & & & & \\
DNA G + C content & 53.05 & $39-44$ & $42.6-45.8$ & 43 \\
(mol\%) & & & & \\
\hline
\end{tabular}

${ }^{\star} \mathrm{A}$, acetate; E, ethanol; F, formate; S, succinate.

flavefaciens, $R$. albus and $R$. callidus (Hungate, 1966; Buchanan \& Gibbons, 1974; De Vos et al., 2009). With cellobiose as the substrate, the isolate grew at $33-39{ }^{\circ} \mathrm{C}$ (optimum $39^{\circ} \mathrm{C}$ ) and at $\mathrm{pH}$ 6.5-6.8 (optimum $\mathrm{pH}$ 6.8). The optimal growth conditions corresponded with those found in the human colon. At $37^{\circ} \mathrm{C}$ on cellobiose $\mathrm{BC}$ medium, the doubling time was $1.9 \mathrm{~h}$ and the maximum optical density $\left(\mathrm{OD}_{600}\right)$ was $1.1-1.3$. Strain $18 \mathrm{P} 13^{\mathrm{T}}$ did not require rumen fluid; growth was similar in cellobiose BC medium (20\% rumen fluid) and in cellobiose semisynthetic BC medium (no rumen fluid).

The phenotypic characteristics of strain $18 \mathrm{P} 13^{\mathrm{T}}$ are compared with those of its closest phylogenetic neighbours in Table 1 . In addition to cellulose, strain $18 \mathrm{P} 13^{\mathrm{T}}$ could utilize xylan and cellobiose but no growth was observed with many other carbohydrates, including starch and glucose. The nutritional capacity of other members of the genus Ruminococcus, in particular $R$. flavefaciens, is reportedly restricted to a limited range of substrates (Hungate, 1966; De Vos et al., 2009) but in the current study the human gut strain $R$. callidus ATCC $27760^{\mathrm{T}}$ was able to use most of the substrates, but notably not cellulose. Strain $18 \mathrm{P} 13^{\mathrm{T}}$ and R. flavefaciens ATCC $19208^{\mathrm{T}}$ were the most similar, but the isolate could be differentiated by the absence of lactose fermentation and no yellow pigment production. Strain $18 \mathrm{P} 13^{\mathrm{T}}$ could be differentiated from $R$. callidus ATCC $27760^{\mathrm{T}}$ by its ability to use cellulose, but not starch, glucose, lactose, maltose, raffinose or sucrose.

Degradation and fermentation of cellulose by strain $18 \mathrm{P} 13^{\mathrm{T}}$ were studied in $\mathrm{BC}$ medium ( $10 \mathrm{ml}$ per tube) containing $100 \mathrm{mg}$ Avicel pH 101, Sigmacell 101 or Whatman no. 1 filter paper cellulose as the sole energy source. The inocula were $0.4 \mathrm{ml}$ of a 5-day-old culture on $\mathrm{BC}$ medium containing Avicel $\mathrm{pH}$ 101. Each incubation time and substrate was tested in triplicate. The kinetics of cellulose degradation were determined by measuring the dry weight of remaining cellulose, as described previously (Robert \& Bernalier-Donadille, 2003). End products of cellulose fermentation were determined using 10-day-old cultures. Gases in the headspace and short-chain fatty acids in the supernatants were analysed by gas-phase chromatography (Robert et al., 2001). The production of formate, succinate, ethanol and lactate was measured using enzymic methods (Roche Boeringher Mannheim). End products of cellobiose fermentation were also determined using 24 -h-old cultures on semi-synthetic $\mathrm{BC}$ medium containing $2 \mathrm{~g}$ cellobiose $\mathrm{l}^{-1}$. Cellulolytic and xylanolytic activities were determined using CM-cellulose, Avicel pH 101 or xylan oat spelt as substrates and measuring the released reducing sugars colorimetrically (Forano et al., 1994; Devillard et al., 1999); glucose and xylose were used as standards and each assay was performed in triplicate. Protein was determined by the method of Bradford (1976) using bovine serum albumin as the standard.

Strain $18 \mathrm{P} 13^{\mathrm{T}}$ could degrade cellulose from different sources (Avicel pH 101, Sigmacell 101 and Whatman no. 1 filter paper; Supplementary Fig. S2, available in IJSEM Online); however, filter paper was degraded most during the 12-day incubation period. CM-cellulase activity $\left[1.4 \pm 0.2 \mu \mathrm{g}\right.$ glucose $\left.(\mathrm{mg} \text { protein })^{-1} \mathrm{~h}^{-1}\right]$ and avicelase activity $\left.[0.9 \pm 0.2 \mu \mathrm{g} \text { glucose (mg protein })^{-1} \mathrm{~h}^{-1}\right]$ was measured in the supernatant fluid of 6-day-old cultures grown with Avicel $\mathrm{pH}$ 101. In addition, xylanase activity $\left[3.3 \pm 0.4 \mu \mathrm{g}\right.$ xylose $\left.(\mathrm{mg} \text { protein })^{-1} \mathrm{~h}^{-1}\right]$ was detected in this culture. Similarly, $R$. flavefaciens has been shown to express both cellulase and xylanase activities (Flint et al., 2008). These enzymic processes may confer an ecological advantage on cellulolytic bacteria by enabling them to access the cellulose fibrils in plant cell walls and the matrix polysaccharides composed of xylan, pectin and mannans that are available within this complex ecosystem. The end products of cellulose fermentation by strain $18 \mathrm{P} 13^{\mathrm{T}}$ were mainly acetate and succinate, with smaller quantities of ethanol, formate and lactate (Supplementary Table S2, available in IJSEM Online). The ratio of acetate and succinate varied according to the type of cellulose provided. In addition, strain $18 \mathrm{P} 13^{\mathrm{T}}$ produced large amounts of $\mathrm{H}_{2}$ during cellulose degradation. Similarly, the cellulolytic species $R$. flavefaciens and $R$. albus ferment cellulose with great production of $\mathrm{H}_{2}$ (Buchanan \& Gibbons, 1974); by contrast, these two species do not produce succinate from cellulose fermentation (Table 1). 
On the basis of phenotypic, genotypic and phylogenetic differences, strain $18 \mathrm{P} 13^{\mathrm{T}}$ could be clearly distinguished from all previously described species of the ruminococci. The isolate's closest phylogenetic neighbours belonged to the genus Ruminococcus in the family Ruminococcaceae (ruminococcal group I) (De Vos et al., 2009; Rainey, 2009a). Therefore, it is proposed to classify the isolate as a representative of a novel species, Ruminococcus champanellensis sp. nov.

\section{Description of Ruminococcus champanellensis sp. nov.}

Ruminococcus champanellensis (cham.pa.nel.len'sis. N.L. masc. adj. champanellensis of or belonging to SaintGenès-Champanelle, where the type strain was first isolated).

Cells are non-motile cocci (up to $1.3 \mu \mathrm{m}$ in diameter) and Gram-stain-positive, with a Gram-positive cell-wall ultrastructure. No heat-resistant endospores are formed. Strictly anaerobic. Cytochrome oxidase- and catalase-negative. Fermentable carbohydrates are required for growth. Ferments only cellulose, cellobiose and xylan; does not ferment other carbohydrates including starch and pectin. Cellulose and cellobiose are metabolized to acetate and succinate. Grows at $33-39{ }^{\circ} \mathrm{C}$ (optimum $39{ }^{\circ} \mathrm{C}$ ) and at pH 6.5-6.8 (optimum pH 6.8). Rumen fluid is not required for growth. Indole-negative, but able to hydrolyse aesculin. Urease is not detected and gelatin is not hydrolysed. Does not grow with glucose, sucrose, fructose, maltose, xylose, galactose, ribose, melibiose, mannose, lactulose, galacturonic acids, lactose, raffinose, arabinose, salicin, trehalose, mannitol, inositol, sorbitol or fucose. Does not produce acid from L-rhamnose, L-sorbose, dulcitol, arabitol, D-adonitol, erythritol, inulin, melibiose, xylitol, gentiobiose, turanose, D-lyxose, D-tagatose, fucose, glycerol, $\mathrm{N}$-acetylglucosamine or amygdalin. With API ZYM, produces alkaline phosphatase, esterase, esterase lipase, naphthol-AS-BI-phosphohydrolase, $\alpha$ - and $\beta$-galactosidases, and $\beta$-glucosidase, but does not produce lipase, leucine arylamidase, valine arylamidase, cystine arylamidase, trypsin, $\alpha$-chymotrypsin, acid phosphatase, $\beta$-glucuronidase, $\alpha$-glucosidase, $N$-acetyl- $\beta$-glucosaminidase, $\alpha$-mannosidase or $\alpha$-fucosidase. The major fatty acids are iso- $\mathrm{C}_{15: 0}$, anteiso- $\mathrm{C}_{15: 0}$, iso- $\mathrm{C}_{15: 0}$ DMA and iso- $\mathrm{C}_{16: 0}$.

The type strain, $18 \mathrm{P} 13^{\mathrm{T}}\left(=\mathrm{DSM} 18848^{\mathrm{T}}=\mathrm{JCM} 17042^{\mathrm{T}}\right)$, was isolated from human faeces of a methane-excreting healthy individual at the INRA centre of ClermontFerrand-Theix, Auvergne, France. The DNA G $+\mathrm{C}$ content of the type strain is $53.05 \pm 0.7 \mathrm{~mol} \%$.

\section{Acknowledgements}

C.R. and C.C. were supported by fellowships from the French Ministère de la Recherche et de l'Enseignement Supérieur. We express many thanks to B. Lassalas for her help with the gas chromatography analyses of fermentation end products and to B. Gaillard-Martinie for assistance with electron microscopy.

\section{References}

Allison, M. J., Bryant, M. P., Katz, I. \& Keeney, M. (1962). Metabolic function of branched-chain volatile fatty acids, growth factors for ruminococci. II. Biosynthesis of higher branched-chain fatty acids and aldehydes. J Bacteriol 83, 1084-1093.

Bernalier, A., Willems, A., Leclerc, M., Rochet, V. \& Collins, M. D. (1996). Ruminococcus hydrogenotrophicus sp. nov., a new $\mathrm{H}_{2} / \mathrm{CO}_{2}$ utilizing acetogenic bacterium isolated from human feces. Arch Microbiol 166, 176-183.

Bradford, D. M. (1976). A rapid and sensitive method for the quantitation of microgram quantities of protein utilizing the principle of protein-dye binding. Ann Bioch 72, 248-254.

Buchanan, R. E. \& Gibbons, N. E. (1974). Bergey's Manual of Determinative Bacteriology, 8th edn. Baltimore: Williams \& Wilkins.

Chassard, C., Delmas, E., Lawson, P. A. \& Bernalier-Donadille, A. (2008a). Bacteroides xylanisolvens sp. nov., a xylan-degrading bacterium isolated from human faeces. Int J Syst Evol Microbiol 58, 1008-1013.

Chassard, C., Scott, K. P., Marquet, P., Martin, J. C., Del'homme, C., Dapoigny, M., Flint, H. J. \& Bernalier-Donadille, A. (2008b). Assessment of metabolic diversity within the intestinal microbiota from healthy humans using combined molecular and cultural approaches. FEMS Microbiol Ecol 66, 496-504.

Chassard, C., Delmas, E., Robert, C. \& Bernalier-Donadille, A. (2010). The cellulose-degrading microbial community of the human gut varies according to the presence or absence of methanogens. FEMS Microbiol Ecol 74, 205-213.

Cummings, J. H. \& Macfarlane, G. T. (1991). The control and consequences of bacterial fermentation in the human colon. J Appl Bacteriol 70, 443-459.

De Vos, P., Garrity, G., Jones, D., Krieg, N. R., Ludwig, W., Rainey, F. A., Schleifer, K. H. \& Whitman, W. B. (editors) (2009). Bergey's Manual of Systematic Bacteriology, 2nd edn, vol. 3. New York: Springer.

Devillard, E., Newbold, C. J., Scott, K. P., Forano, E., Wallace, R. J., Jouany, J. P. \& Flint, H. J. (1999). A xylanase produced by the rumen anaerobic protozoan Polyplastron multivesiculatum shows close sequence similarity to family 11 xylanases from gram-positive bacteria. FEMS Microbiol Lett 181, 145-152.

Eckburg, P. B., Bik, E. M., Bernstein, C. N., Purdom, E., Dethlefsen, L., Sargent, M., Gill, S. R., Nelson, K. E. \& Relman, D. A. (2005). Diversity of the human intestinal microbial flora. Science 308, 1635-1638.

Flint, H. J., Bayer, E. A., Rincon, M. T., Lamed, R. \& White, B. A. (2008). Polysaccharide utilization by gut bacteria: potential for new insights from genomic analysis. Nat Rev Microbiol 6, 121-131.

Forano, E., Broussolle, V., Gaudet, G. \& Bryant, J. A. (1994). Molecular cloning, expression and characterization of a new endoglucanase gene from Fibrobacter succinogenes S85. Curr Microbiol 28, 7-14.

Hungate, R. E. (1966). The Rumen and Its Microbes. London, New York: Academic Press.

Hungate, R. E. (1969). A roll tube method for cultivation of strict anaerobes. Methods Microbiol 3B, 117-132.

Leitch, E. C., Walker, A. W., Duncan, S. H., Holtrop, G. \& Flint, H. J. (2007). Selective colonization of insoluble substrates by human faecal bacteria. Environ Microbiol 9, 667-679.

Lipman, D. J. \& Pearson, W. R. (1985). Rapid and sensitive protein similarity searches. Science 227, 1435-1441.

Liu, C., Finegold, S. M., Song, Y. \& Lawson, P. A. (2008). Reclassification of Clostridium coccoides, Ruminococcus hansenii, Ruminococcus hydrogenotrophicus, Ruminococcus luti, Ruminococcus productus and Ruminococcus schinkii as Blautia coccoides gen. nov., 
comb. nov., Blautia hansenii comb. nov., Blautia hydrogenotrophica comb. nov., Blautia luti comb. nov., Blautia producta comb. nov., Blautia schinkii comb. nov. and description of Blautia wexlerae sp. nov., isolated from human faeces. Int J Syst Evol Microbiol 58, 18961902.

Nicholas, K. B., Nicholas, H. B., Jr \& Deerfield, D. W., II (1997). GeneDoc: analysis and visualization of genetic variation. EMBNet News 4 (2), 14.

Page, R. D. M. (1996). TreeView: an application to display phylogenetic trees on personal computers. Comput Appl Biosci 12, 357-358.

Qin, J., Li, R., Raes, J., Arumugam, M., Burgdorf, K. S., Manichanh, C., Nielsen, T., Pons, N., Levenez, F. \& other authors (2010). A human gut microbial gene catalogue established by metagenomic sequencing. Nature 464, 59-65.

Rainey, F. A. (2009a). Family VIII. Ruminococcaceae fam. nov. In Bergey's Manual of Systematic Bacteriology, 2nd edn, vol. 3, pp. 10161043. Edited by P. De Vos, G. M. Garrity, D. Jones, N. R. Krieg, W. Ludwig, F. A. Rainey, K.-H. Schleifer \& W. B. Whitman. New York: Springer.

Rainey, F. A. (2009b). Family V. Lachnospiraceae fam. nov. In Bergey's Manual of Systematic Bacteriology, vol. 3, pp. 921-968. Edited by P. De Vos, G. M. Garrity, D. Jones, N. R. Krieg, W. Ludwig, F. A. Rainey, K.-H. Schleifer \& W. B. Whitman. New York: Springer.

Rainey, F. A. \& Janssen, P. H. (1995). Phylogenetic analysis by $16 \mathrm{~S}$ ribosomal DNA sequence comparison reveals two unrelated groups of species within the genus Ruminococcus. FEMS Microbiol Lett 129, 6973.
Ramirez-Farias, C., Slezak, K., Fuller, Z., Duncan, A., Holtrop, G. \& Louis, P. (2009). Effect of inulin on the human gut microbiota: stimulation of Bifidobacterium adolescentis and Faecalibacterium prausnitzii. Br J Nutr 101, 541-550.

Rasmussen, S. W. (2002). SEQtools, a software package for analysis of nucleotide and protein sequences. http://www.seqtools.dk

Robert, C. \& Bernalier-Donadille, A. (2003). The cellulolytic microflora of the human colon: evidence of microcrystalline cellulose-degrading bacteria in methane-excreting subjects. FEMS Microbiol Ecol 46, 81-89.

Robert, C., Del'Homme, C. \& Bernalier-Donadille, A. (2001). Interspecies $\mathrm{H}_{2}$ transfer in cellulose degradation between fibrolytic bacteria and $\mathrm{H}_{2}$-utilizing microorganisms from the human colon. FEMS Microbiol Lett 205, 209-214.

Saitou, N. \& Nei, M. (1987). The neighbor-joining method: a new method for reconstructing phylogenetic trees. Mol Biol Evol 4, 406425.

Salminen, S., Bouley, C., Boutron-Ruault, M. C., Cummings, J. H., Franck, A., Gibson, G. R., Isolauri, E., Moreau, M. C., Roberfroid, M. \& Rowland, I. (1998). Functional food science and gastrointestinal physiology and function. Br J Nutr 80 (Suppl 1), S147-S171.

Stackebrandt, E. \& Ebers, J. (2006). Taxonomic parameters revisited: tarnished gold standards. Microbiol Today 33, 152-155.

Stackebrandt, E. \& Goebel, B. M. (1994). Taxonomic note: a place for DNA-DNA reassociation and $16 \mathrm{~S}$ rDNA sequence analysis in the present species definition in bacteriology. Int J Syst Bacteriol 44, 846849. 